POLLACK PERIODICA

An International Journal for Engineering and Information Sciences

DOI: $10.1556 / 606.2018 .13 .1 .15$

Vol. 13, No. 1, pp. 169-179 (2018)

www.akademiai.com

\title{
CONCEPTS FOR WATERFRONT DEVELOPMENTS, FOCUSING ON SIOFOK, HUNGARY
}

\author{
${ }^{1}$ Janos GYERGYAK, ${ }^{2}$ Ge DAN, ${ }^{3}$ Peter PAARI \\ ${ }^{1}$ Department of Architecture and Urban Planning, Faculty of Engineering and Information \\ Technology, University of Pécs, Boszorkány u. 2, H-7624 Pécs, Hungary \\ e-mail: gyergyak.janos@mik.pte.hu \\ ${ }^{2}$ Marcel Breuer Doctorate School, Faculty of Engineering and Information Technology \\ University of Pécs, Boszorkány u. 2, H-7624 Pécs, Hungary \\ Department of Art and Design, Faculty of Fine Art, Shandong Normal University \\ Wenhua East u. 88, 250014, Jinan, China, e-mail: gedan82@163.com \\ ${ }^{3}$ Marcel Breuer Doctorate School, Faculty of Engineering and Information Technology \\ University of Pécs, Boszorkány u. 2, H-7624 Pécs, Hungary, e-mail: paari.peter87@gmail.com
}

Received 18 June 2017; accepted 25 October 2017

\begin{abstract}
The paper shows a general introduction about the connection of cities, particularly Siófok, the 'capital' of Lake Balaton and water surfaces through three topics: the first part deals with the past and present of waterfronts, by exploring the most important principles in their design, then describes the significant tools and methods of the Hungarian cities around Lake Balaton, the most important water surface of Hungary, related to the areas adjacent to the water. Finally, it reveals a complex design work by the authors for refurbishing the waterfront in Siofok, based on a national competition.
\end{abstract}

Keywords: Waterfront development, Hungarian urban development concept, Waterfront design, Port rehabilitation, Public spaces

\section{Waterfront developments in general}

Water is the origin of life and human activities are inseparable from this liquid element. Most of the early cities were formed in the coastal areas near rivers and lakes like Babylonian of Babylon, the De Beas of ancient Egyptian De Beas. The river is not only the most important water source of urban residents, who are living and performing industrial production, but also the main channel of urban transport. The development of medieval European cities is mainly based on handicrafts and long-distance commercial trade. The status of a city is mostly determined by its trade capacity. Waterfront cities, especially those in the river interchange, relying on convenient traffic conditions, become a trans-shipment point of commodity trade, thus developing rapidly. Barcelona, the second largest city of Spain, the earliest settlement appeared in the coastal zone in 
the $5^{\text {th }}$ century $\mathrm{BC}$, precisely for trade reasons and thus developed into a trading port and the most important commercial city of the Mediterranean. In the busiest era of water transport, waterfront areas like ports became the main space of urban public communication. The waterfront area not only gathered a large number of terminals and freight warehouses, but also gathered a variety of related industries and facilities. Port and city life mixed together on the waterfront and became traffic, commercial and cultural center of the city.

Since the beginning of the industrial revolution, industrial areas have increasingly been gathered to the waterfront. This is because the industrial site in the riverside area, not only can facilitate to take sewage water, but also can take advantage of convenient water transport conditions. The increase in trade volume has promoted the port area to a large-scale and professional location. The demand for industrial capital makes the living function of the waterfront excluded. The residential, commercial and cultural facilities, which originally gathered in the waterfront, have been degraded and migrated. The waterfront has become the production and transportation core of the city. The development of industrial capital has greatly promoted the development of the waterfront, and brought the whole city into the era of industrialization, but also resulted in many shortcomings. A large amount of industrial and domestic sewage was discharged into the river; therefore the natural environment of the river was severely damaged.

In 1960s, with the worldwide adjustment of industrial structure, waterfront areas experienced an inverse industrialization process. Industry, transport facilities and ports moved away from the central city. This phenomenon involved the migration of industrial enterprises from urban to suburban areas or from developed countries to developing countries (from Europe to Southeast Asia). The productive function of the waterfront gradually weakened. The original factory, warehouse, railway station, port were abandoned.

Since the 1970s the economic production has entered a new stage. The driving force of social development has shifted from production to consumption. With the rise of the middle class and the change of labor style, the material and spiritual living standards of the residents have significantly improved. Having more leisure time, and the demand for ecological environment, tourism and leisure are increasing. At the same time, the values of people have changed. People began to realize that the waterfront is a living and usable resource, not just an ugly abandoned land with broken form. In fact, the waterfront area, which occupied the core location of the city, has the possibility of function conversion, and the cost is low, the demolition is small. Due to the city-scale expansion, the city began to develop across the river. The waterfront area has altered from the edge of the city to the city center. The importance of the waterfront in the city has been highlighted, making it an ideal public open space.

The reconstruction and development of the urban waterfront first appeared in some important cities in North America, followed by rapid deployment in European cities. There are a number of distinctive examples, like the waterfront development of Barcelona through urban events, the reservation and re-understanding of the port and industrial history of Hamburg. These successful waterfront development projects have similar regeneration strategies. 


\subsection{Mixed use function}

In order to produce an attractive urban atmosphere, waterfront development usually sets up leisure, entertainment, dining, shopping and other facilities. The French city Marseille, considering the needs of a wide range of people, created a transport hub, public space, office space, residential, commercial, hotel, cultural facilities and leisure venues [1]. Through the mixed use of urban functions a public living circle and a waterfront cultural space were formed. Hamburg specifically proposed an 'Art One mile' program - connecting the Old Town Center and Port Metro with various arts and cultural facilities [2]. The mile-long art axis starts on the banks of the Ulster Lake, with museums, galleries, antique shops, art houses, cafes and bistros on both sides of the street, extended to the museum and cultural facilities of the harbor area.

\subsection{Creating a diversified open space and forming a continuous open space system}

Urban public space attracts diverse groups of people and organizes urban events. In the process of renewing the old town, Marseille paid special attention to the design of the open space along the old harbor [3]. The cruise ship and port function were moved to the floating port. The space around the old harbor coastline was changed into a park and playground. The multi-level public space with square, cultural park, community activities was formed. The visibility of the coastline corridor was maintained through the control of the waterfront streets. The surrounding square and the port terrace combined with another open space formed a rich coastal landscape interface (Fig. 1).

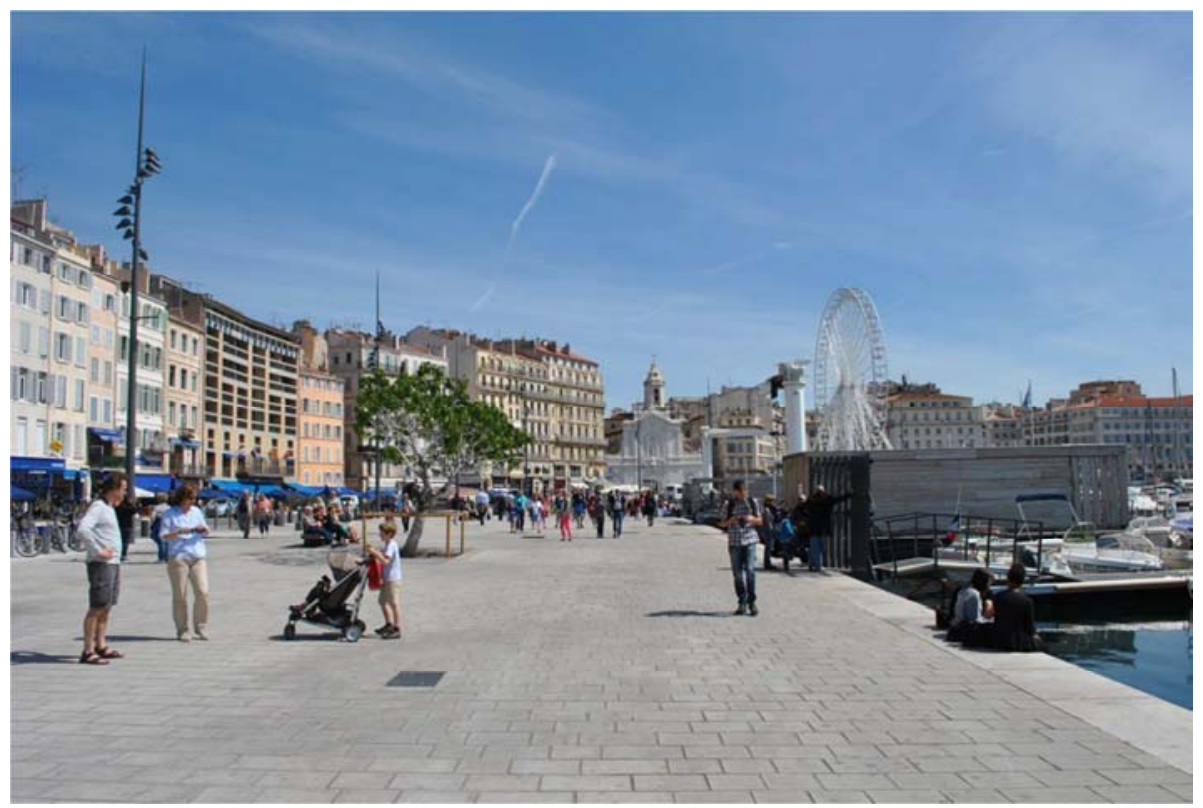

Fig. 1. Photo about the refurbished 'Old port of Marseille' (Le Vieux Port de Marseille), Photo by János Gyergyák 


\subsection{Paying attention to the creation of hydrophilic space and sight to the water}

Water features have always fascinated human beings. The creation of hydrophilic space is to rebuild the intimate relationship between people and the environment. The design of the Baltimore Inner Harbor in the United States, highlighting the waterthemed design concept, was maximized to provide the facilities and conditions in order to see water, near water and play water [4]. The plan used a 'U-shaped' Waterfront walkway as a link, connecting the activities of the inner harbor to make the waterfront environment a common space for the public.

\subsection{Increasing the accessibility of the waterfront, and encouraging pedestrian traffic}

The vitality of waterfront space is closely related to its accessibility. The more opportunities for people to reach the waterfront exist, the more people can resonate with the waterfront environment. In order to ensure the safe and convenient access to the waterfront environment, people and vehicles are usually separated. With the support of fast traffic, people were encouraged to walk in the waterfront area. During the preparation of the 1992 Olympic Games, Barcelona carried out a large-scale reconstruction of the infrastructure [5]. The road was re-planned and organized; the rapid road along the seaside was under the ground. The urban space and waterfront, once blocked by traffic, is re-linked together. Visitors can walk from the city center to the waterfront to enjoy the waterfront life, which is no longer blocked by the elevated road or freight traffic.

The redevelopment of the waterfront is a good countermeasure and measure for the revival of global urban regeneration. It transforms the industry of the past, warehousing and transportation into a vibrant place for public activities, with the creation of attractive and distinctive public spaces. Its main task is to create an attractive, rich and special public space. The high-quality public space not only enhanced the comfort of the waterfront area, but also helped to improve the value of the surrounding area, and developed the overall image of the city.

\section{Waterfront development methods around Lake Balaton, Hungary}

In Hungary the connection of cities and water surfaces can be analyzed the best by the River Danube, which is a key geographical water element of the country being working as an important water link among countries and settlements, and by the Lake Balaton, the biggest lake in Central Europe.

As a second element in the development of tourism, Lake Balaton was chosen to be the subject of this research because the whole area of the lake is a key tourist attraction, which fact was declared by making the Hungarian CXII. law [6] "Approval of the Highlighted Territorial Planning of the Balaton Resort and the establishment of the Balaton Area Planning Code.'

The national law mostly provides regulations about land use, nature and water protection, but it needs proposals for the development of public spaces along coastal areas [7]. The most decisive regulation element says that 'along the priority holiday resort areas in all coastal settlements, at least $30 \%$ public promenade must be 
implemented based on water rehabilitation plans, taking the natural vegetation into account' [6].

After this mild regulation based on the development of waterfront areas, mostly focusing on public and not private spaces, the scale of the research was shifted to city level and City Development Concepts and 'Integrated Urban Development Strategy' were analyzed in the most determinant cities around Lake Balaton like Siófok, Balatonlelle, Balatonboglár, Fonyód, Balatonfenyves, Keszthely, Balatonfüred. Answers were searched for the following questions; what do the cities think about the connection of land and water, and how do these development strategies/concepts deal with the Lake Balaton?

The development, connected to the water surface, has an important role in the 'Integrated Urban Development Strategy of Siófok' [8]. The development of the sailboat and yacht port is a main element of the innovation. Nowadays the Sio canal is idle; however, it is a useful innovation in this project, which was planned to control the level of water. In the development program there is a possibility for the complex usage of the area. The development of the port and its environment is planned within 20172023. The project has 8 parts and 7 of these are connected to the water surface.

According to the 'Integrated Urban Development Strategy of Balatonboglár' the innovation of Lake Balaton as a water habitat and the ecology of other natural areas is a main task [9]. In this task Lake Balaton is an independent unit by law and a natural economic viewpoint as well. The more incorporation of the shore is prevented with increasing the green and self-cleaning areas. In the future the development of the passenger ship port is planned according to perspective need. The new sailboat port is appointed next to the current port. There is a free beach in Balatonboglár, which is not a usual concept at Lake Balaton.

The innovation of the recreation area has a main role in the 'Integrated urban Development Strategy of Fonyód' like the development of water sports, sailboat and boat port [10]. The plan mentions the correction of the conditions regarding water tourism.

According to the program in the City Development Concepts of Keszthely the goal is to make a better connection between the life of citizens and leisure time functions [11]. In order to develop free time activities on the shore promenade, the public areas and fishing tourism have been improved.

The future or planned developments of the waterfront can easily be understood through the most important finished projects along Lake Balaton. Shipping tourism was aimed with the port built in 2016. This is a yacht and sailboat port, which was planned in the 90s. On the 4-hectare area there are more than 300 docks, a 3-star hotel and a bicycle center, a restaurant and a playground. Balatonfenyves is meant to be 'the gate of Balaton' and water tourism has increased with these investments [12]. In order to reach this target, a ship rental system was planned as in other towns and cities there are bicycle rental systems.

Balatonfüred has a main role in the innovations at Lake Balaton. The main field of the investment is sailing, beach sports and extreme sports possibilities. The plan of the city is to make Lake Balaton the cultural lake of Europe. Another element of the investment is the rehabilitation of the Tagore promenade. The nature and feeling of the promenade will not change the connection of the water and shore will be more direct by 
means of constructing a pier and the shore promenade. The beach of the hotel Annabella will be opened out of season, so there will be a 500-meter long promenade with this change.

In 2016, the so-called capital of Lake Balaton, Siófok announced a national competition to search for the best ideas for 'Complex long-term development plan of the central resort area in Siófok'.

The objective of the architectural competition was to look for the long-term development of the recreation center, create a unique, world-class image for one of the oldest and most well-known areas of Siófok town [8]. The central element of the design was the alteration of the shipping island, the marina, the pier, the Rose Garden, the coherent fabric of the Great Beach and Petöfi Promenade. The city was searching for complex ideas based on very significant concepts of new land use, public spaces design, and tourism attraction (buildings). The previously mentioned elements are parts of four areas in Siófok, having water surface connection, but there are differences regarding their characters.

The west part of the port: The border of the west side of the port is the Vitorlás Street'. There is a sailboat port near Lake Balaton, as well as two hotels and the Meteorology Institute. There are complementary functions in the middle belonging to the sailboat port e.g. shop, hangar, the place of the crane. There is restaurant in the southern part.

The central part of the port with the peninsula and island: The middle of the port is the most determining part. In the perspective of Lake Balaton there are two important functions. The main port of shipping on Balaton is here. In winter ships and boats are stored and repaired here. The second main function is connected to the Sió canal. The water supply of Balaton is ensured by two water work constructions: the flood gate and the ship lock.

The eastern part of the port: The border of the eastern part of the port is Mártírok Street. The ship station can be reached from the Krúdy promenade. In this part of the port there are different type of buildings e.g. ship station, places for relaxation and public administration buildings. The area is bordered by parks.

The eastern part of the coast: This area is between the Istria promenade and Petöfi promenade and bordered by Tátra Street. The shore promenade, Rózsakert and the hotels are determining elements of this area. The beach and pedestrian street contain restaurants, bars and other shops here. The tourist functions do not show a unified character. This is a new city axis e.g. new residential area and new hotels have to get a new interpretation. The main target of the competition was the boost of sailboats and water-life. And the other important task was to help shipping and water supply with constructing the missing functions even with transforming these functions. The expectation of the competition was the shore promenade revaluation. A bath city identity was planned by means of aiming this target. The city is known as a center of bathing and party tourism at Lake Balaton. The physical and functional reformation was considered as the target of the innovation, which could be an exciting tourist destination. 


\section{A concept for complex development of the waterfront in Siófok, Hungary}

The race between cities is more acute. Ivan Bofarull, in his article noted that 'urbanization' as one of the most important element for the success of the cities, [13].

The proposal for the 'Complex long-term development plan of the central resort area in Siófok' was started with a very comprehensive observation about the planning area, and its close surroundings. The issue of urban development requires strategic thinking. It includes self-sustainable mechanisms, strengthening self-organization and financing of the cities, collectively [14]. The sustainable thinking is mostly an obligatory approach in the nowadays urban thinking to avoid the exaggerating ideas [15].

The goal was to create a plan, which is based on a very comprehensive action plan, and call for all the participants for common action. According to some very fresh study and design strategy, the partnership and cooperation will be the key role and challenge for the cities in the future [16].

The city development can be reached through using the unused or lost areas and rehabilitate them. The success in this area can be very significant if the re-design deals with the different type of human activity, like perceived space, conceived space and lived space [17]. The found problems were combined with the isolated land use, the dominant industrial function in the center and the lack of attractions, (Fig. 2). The development concept of the designated areas must primarily address the transformation of these issues. In addition, car traffic should be replaced by 'man-cantered' pedestrian surfaces focusing on the extension of walk-able areas (Fig. 3).

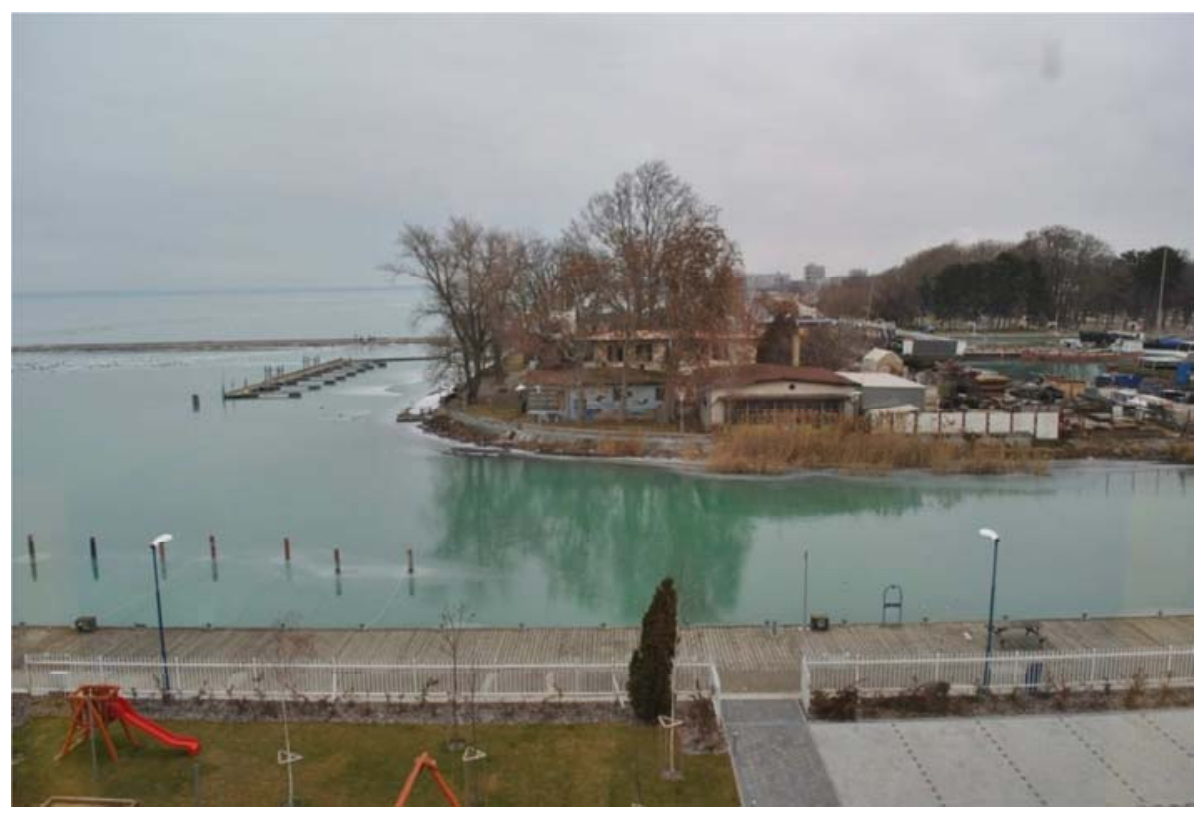

Fig. 2. Photo about the existing conditions of the port with the peninsula and island (development area 02), photo by János Gyergyák 
The development plans were distinguished according to the different characteristics of the four areas like western [01], central [02] and eastern [03] part of the port, and the eastern part of the coast [04].

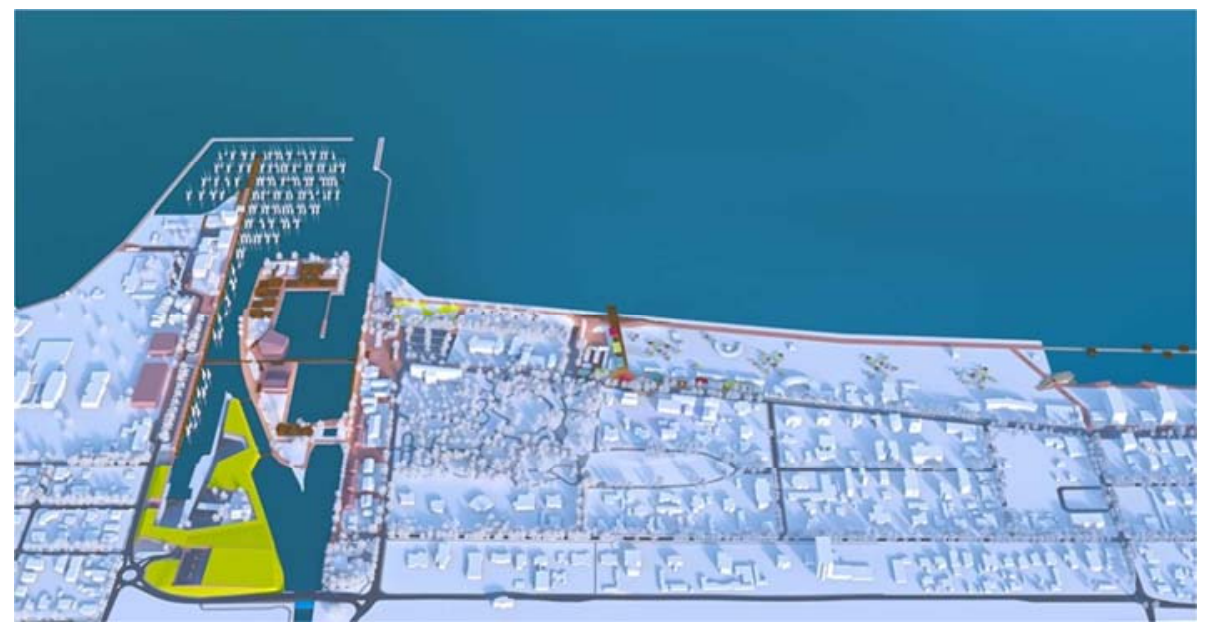

Fig. 3. The overview design proposal by the authors for renewing the waterfront areas

\section{The western part of the port (development area 01)}

The western part of the port consists of the marina and the related area of services. The given functions were placed in a 6-meter-wide 'ribbon-like' wavy building on the western side of the port to serve sailors. The new social and community rooms were formed in the north, shops in the middle and workshops together with the winter storage facilities in the south area, near the industrial area.

In the framework of the design program the marina was requested to be developed from the southernmost point of the island towards Lake Balaton, as well as in the direction of the west, so the new pier can operate more efficiently due to its bilateral construction.

\section{The central part of the port with the peninsula and island (development area 02)}

The two main users of the plan, the Balaton Shipping Co. Ltd and the Balaton Water Management Office of the Central Transdanubian Water Directorate, have been moved from the island to the peninsula. The newly formed industrial area has been transformed into an artificial hill, which dominates the peninsula, but it is nearly hidden from the external environment. The industrial area opens inwards, and by means of retraction, an independent space were created as a work area (an office building to be held, see in the overall visualization).

South from the new industrial buildings, between the bridge and the road elevating onto it, 3-storey car park was designed from the east masked with an artificial hill. The 
main parking space (P300) can serve the western (marina) and the eastern parts (touristic functions) of the port at the same time.

This new construction creates an opportunity to utilize the newly-freed areas for touristic purposes, which can be the new center of not only Siófok, but the gastronomical, entertainment and cultural capital of the Balaton region. Regarding the industrial functions, the preservation of the sluices and the two buildings were suggested at the northernmost point of the island, since the other buildings do not represent significant architectural values (Fig. 4).

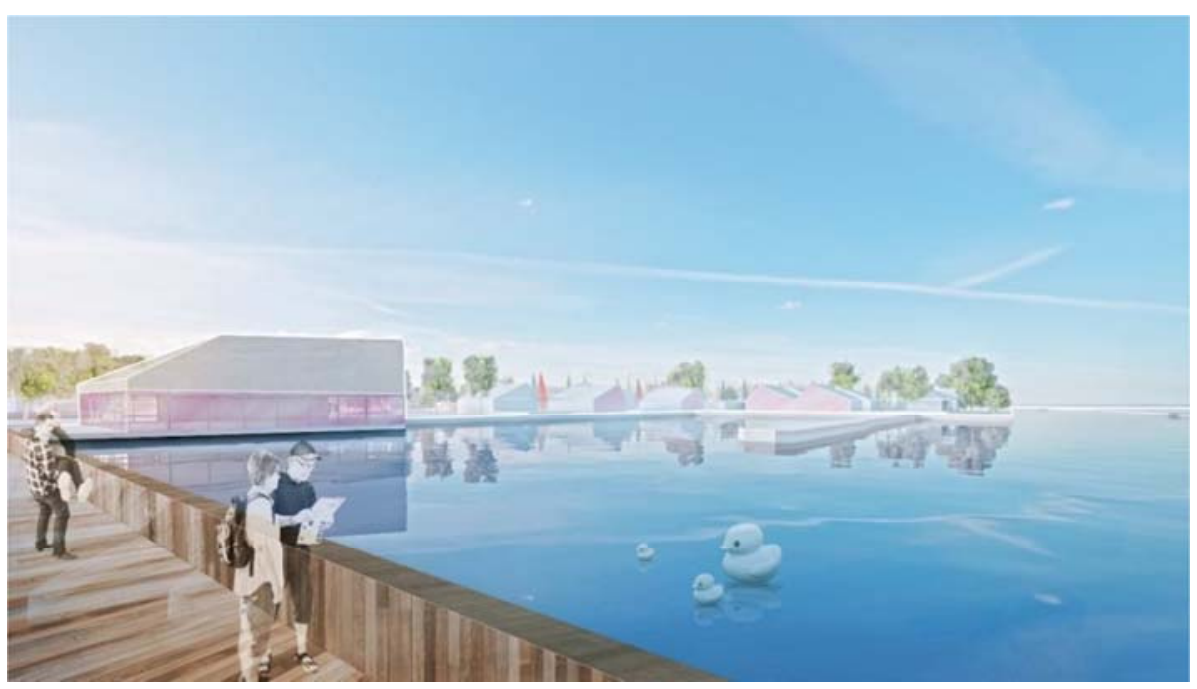

Fig. 4. Visualization about the new cultural and gastronomy island in the heart of Siofok (development area 02)

\section{The eastern part of the port (development area 03)}

The main task of the area is to organize the passenger ship traffic and meet touristic demands. Regarding the former function, a new passenger traffic building was placed in the northern part of the new events square, which is located on the imaginary stretching of Petöfi promenade, near the waterside. In order to develop touristic functions, a partial reconstruction of the block bordered by Krúdy promenade and Mártírok Street was suggested.

In the northern part of the area, a lookout tower was recommended, which is the emblematic pair of the water tower in the city center, as a stretching of the new events square overlooking the port, towards Mártírok Street, the Golden and Silver Coast, as well as the northern part (with a 30-meter-high floor level, matching the floor level of Oxigénbár club) of Lake Balaton. 


\section{The eastern part of the coast (development area 04)}

In order to give additional value to the coastal promenade, a 'dry dock' have been created, which stretches to the beach area (connects only visually to the beach). The Petöfi promenade is 'simplified' through the effect of 'Petöfi pier'. With the newly formed spaces, the promenade can have a visual connection with the beach and the waterside again. The unification of the beach areas of vastly different atmosphere were recommended by means of shades, humidity gates and lightweight structures placed on the pier, in pastel color.

A new 'pier system' was added to the front of the hotels, on the one hand to restrict the water surface in front of the hotels (family and children friendly environment), on the other hand, other functions were proposed on the platforms (sunbathing terrace, waterside bar, etc.) placed on the water surface. The new attraction of the area is the sauna house (health house), which can be considered as a main pillar to utilize the location during the whole year.

\section{Conclusion}

The waterfront areas are more stressed since the changes in economics; shifting the industrial economy to the direction of tourism. The transformation of the waterfronts of the cities have been changing slowly, but there are more and more important requirements for making these places more humane and walk-able providing more open spaces and mixed used functions.

In Hungary, the mentioned process has started but the existing environment needs to be replaced by many new features based on human-scaled projects. The connections of the waterfront and the built environment were neglected. The quality and quantity of these areas were not among the key development issues but the new development programs contain the process and goals. First of all, these areas should be re-humanized by creating more open public spaces with different type of attractions based on water, aiming the very diverse range of humans.

The proposed public spaces with good and comprehensive plans can make users happier by creating spaces for more people. Hence, the spaces, which attract more people, are in close connection with business; having more people means more profit, which improves the local economy so the interventions and transformation not just influence the physical surrounding but the life of the local community and economic, either.

\section{References}

[1] Chen K., Lou Q., Zhao Y. Revitalization of port city interface: A case study of Vieux Port in Marseille, Urban Development Studies, Vol. 23, No. 4 2016, pp. 33-37.

[2] Yang M. European waterfront space, Interior Design, No. 3, 2010, pp. 41-45.

[3] Zhan Y. Study on regeneration design of seafront harbor area from the perspective of urban humanities - Take Marseille, France as an example, Planning Annual Conference Proceedings, Shen Yang, China, 24 September 2016, pp. 500-509. 
[4] Zhang T., Ding H., Peng Z. Development and design of urban waterfront, Shang Hai, Tongji University, 2002.

[5] Busquers J. Barcelona the urban evolution of a compact city, Harvard University, 2005.

[6] $\$ 20$ in 2000 year CXII. law Article about accepting the Spatial Planning Plan of the Lake Balaton's featured holiday resort and the statement the Lake Balaton's Spatial Planing Policy, in Integrated Urban Development Strategy, Vol. III, (in Hungarian) https://net.jogtar.hu/jr/gen/hjegy_doc.cgi?docid=A0000112.TV, (last visited 5 May 2017).

[7] Wettstein D. Historical analysis of regional planning of Balaton, Pollack Periodica, Vol. 8, No. 1, 2013, pp. 141-152.

[8] Spatial planning concept and integrated urban development strategy of Siófok, in Integrated Urban Development Strategy, Vol. III, (in Hungarian), http://siofok.hu/files/ ITS_Siofok_VeGSo.pdf, (last visited 5 May 2017).

[9] Integrated urban development strategy of Balatonboglár, in Integrated Urban Development Strategy, Vol. II, (in Hungarian), http://www.balatonboglar.hu/media/files /bb_ivs_100130_vegleges_palyazat hoz.pdf, (last visited 5 May 2017).

[10] Integrated urban development strategy of Fonyód, in Integrated Urban Development Startegy, Vol. II, (in Hungarian), http://its-tk-dokumentumok.terport.hu/sites/default/files/ egyebdoksicsatolmany/fonyod_its_05_07_vegso.pdf, (last visited 5 May 2017).

[11] Integrated urban development strategy of Keszthely, in Integrated Urban Development Strategy, Vol. III, (in Hungarian), https://www.keszthely.hu/webimages/files/ Keszthely\%20Varos\%20Integralt\%20Telepulesfejlesztesi\%20Strategiaja\%2020142020.pdf, (last visited 5 May 2017).

[12] Baseline study, Review of settlement planning tools of Balatonfenyves (in Hungarian), http://webcache.googleusercontent.com/search?q=cache:liqIt_eXavIJ:www. balatonfenyves.hu/fenyves1/index.php/hu/onkormanyzat/letoeltesek-dokumentumok/ doc_download/309-megalapozo-vizsgalat $+\& \mathrm{~cd}=1 \& \mathrm{hl}=\mathrm{hu} \& \mathrm{ct}=\mathrm{clnk} \& \mathrm{gl}=\mathrm{hu} \& \mathrm{client}=$ firefoxb-ab, (last visited 5 May 2017).

[13] Bofarull I. Success and the city, EFMD Global Focus, the Business Magazine, Vol. 10, No. 1. pp. 48-51.

[14] Kovacs E. City success index, urban development, a possible method to research urban strategy, Pollack Periodica, Vol. 11, No. 3, 2016, pp. 27-42.

[15] Kovacs-Andor K. Sustainable development of the town center of Visegrád, Pollack Periodica, Vol. 11, No. 1, 2016, pp. 157-161.

[16] Kaspar D. Partnership and cooperation - A challenge for democratic cities in the 21st century, Aspen Review, No. 1, 2017. pp. 104-107.

[17] Beri M. Detected space, thoughtful space, lived space: The tripartite of spatiality is an example of a brownfield rehabilitation berth in Budapest, Tér és Társadalom, Vol. 31, No. 2, 2017, pp. 23-43. 